\title{
KOMBINASI STRATEGI PEMBELAJARAN DENGAN MOTIVASI BELAJAR DALAM MENINGKATKAN KETERAMPILAN MENULIS KARANGAN DESKRIPSI OLEH SISWA KELAS X SMAN 2 BERASTAGI KABUPATEN TANAH KARO TAHUN PEMBELAJARAN 2016-2017
}

\author{
Mimi Rosadi ${ }^{1}$ \\ Sujarwo $^{2}$ \\ Universitas Muslim Nusantara [UMN] Al-Washliyah
}

\begin{abstract}
Abstrak
Tujuan penelitian ini adalah untuk memperoleh data dan informasi, serta untuk mengetahui kombinasi stategi pembelajaran dengan motivasi belajar dalam meningkatkan keterampilan menulis karangan deskripsi. Target luaran penelitian ini diterbitkan ke dalam jurnal ilmiah dan prosiding. Metode penelitian ini adalah eksperimen dengan disain faktorial $2 \times 3$. Data hasil penelitian dianalisa secara statistik deskriptif dan inferensial. Sebelum tahap inferensial diawali dengan uji normalitas dan homogenitas. Pada tahap inferensial menggunakan analisisvarians dua jalur. Yang dilajutkan dengan uji Tukey jika terdapat interaksi antara strategi pembelajaran dengan motivasi belajar.
\end{abstract}

Kata Kunci: strategi pembelajaran, motivasi belajar, dan keterampilan menulis karangan d0eskripsi

\begin{abstract}
The purpose of this study is to obtain data and information, as well as to know the combination of learning strategies with learning motivation in improving writing skill description. Output targets of this research are published into scientific journals and proceedings. This research method is experiment with $2 \times 3$ factorial design. Data of research result analyzed in descriptive and inferential statistic. Before the inferential phase begins with a test of normality and homogeneity. At the inferential stage using twolane analysis variance. Continued with the Tukey test if there is an interaction between learning strategies and learning motivation.
\end{abstract}

Keywords: learning strategy, learning motivation, and writing skills essay description

\section{Pendahuluan}

\subsection{Latar Belakang Masalah}

Pembelajaran adalah suatu kombinasi yang tersusun atas manusiawi,material, fasilitas, prosedur, dan perlengkapan yang saling mempengaruhi demi mencapai tujuan pembelajaran.

$$
\text { Pembelajaran }
$$

juga merupakan suatu proses yang rumit karena tidak sekedar menyerap informasi dari guru, tetapi melibatkan berbagai kegiatan dan tindakan yang harus dilakukan untuk mendapatkan hasil belajar yang baik. Salahsatu kegiatan 
pembelajaran yang menekankan pada berbagai kegiatan dan tindakan yaitu menggunakan model dan metode serta media pembelajaran. Model, metode dan media pembelajaran merupakan cara teratur dalam proses pembelajaran dan untuk memperoleh kemampuan siswa dalam mengembangkan materi yang diajarkan oleh guru.

Dalam proses pembelajaran terjadi hubungan timbal balik (interaksi) antara guru dengan siswa.Dalam interaksi tersebut guru berperan sebagai motivator dan fasilitator dalam belajar. Guru dituntut mampu menciptakan situasi pembelajaran yang kondusif, yaitu pembelajaran aktif, kreatif, inovatif, efektif dan menyenangkan dalam proses kegiatan pembelajaran.

Situasi yang kondusif dapat membuat kegiatan pembelajaran tidak membosankan dan siswa akan lebih mudah menyerap informasi yang diberikan. Tetapi pada kenyataannya situasi yang kondusif dalam kelas sulit untuk diwujudkan. Siswa diposisikan sebagai pendengar ceramah dari guru dalam proses pembelajaran, sehingga proses pembelajaran cenderung membosankan dan menjadikan siswa malas belajar. Sikap anak didik yang pasif dan malas tidak hanya pada mata pelajaran tertentu tetapi hampir terjadi pada semua mata pelajaran termasuk bahasa Indonesia khususnya dalam menulis karangan deskripsi,dimana siswa hanya diarahkan oleh guru untuk mengkhayalkan objek tanpa melihat bentuknya sendiri.

Dalam hal ini peneliti berupaya untuk memperkenalkan startegi pembelajaran yang mengkombinasikan strategi SFAE dengan ENE dalam mencapai hasil karangan deskripsi yang baik. Strategi pembelajaran SFAE merupakan strategi yang mengarahkan siswa untuk mempresentasikan ide atau pendapatnya secara inovatif (Purnitawati,2011:21). Siswa diarahkan untuk menyampaikan pendapatnya setelah mendengarkan penjelasan dari guru. Strategi SFAE dikombinasikan dengan strategi ENE dimana siswa diarahkan untuk memperhatikan sebuah gambar yang ditampilkan dari OHP atau gambargambar dari guru kemudian dideskripsikan dengan 
menggunakan strategi pembelajaran SFAE.

Kombinasi strategi ini dapat memunculkan motivasi belajar siswa yang dapat menghasilkan nilai yang cukup memuaskan dalam keterampilan menulis karangan deskripsi yang selama ini dianggap oleh siswa sulit dalam mendeskripsikan sebuah gambar. Berdasarkan latar belakang yang dipaparkan,maka peneliti tertarik untuk mengangkat judul penelitian yaitu : Kombinasi strategi pembelajaran dengan motivasi belajar dalam meningkatkan keterampilan menulis karangan deskripsi oleh siswa kelas X SMAN 2 Brastagi kabupaten tanah karo tahun pembelajaran 2016-2017.

\subsection{Tujuan Penelitian}

Adapun tujuan dalam penelitian ini adalah sebagai berikut :

a. Untuk mengetahui pengaruh strategi pembelajaran SFAE terhadap motivasi belajar tingkat tinggi dalam keterampilan menulis karangan deskripsi siswa kelas X SMAN 2 Brastagi tahun pembeleajaran 2016-2017.

b. Untuk mengetahui peningkatan strategi pembelajaran ENE terhadap motivasi belajar tingkat sedang dalam keterampilan menulis karangan deskripsi oleh siswa kelas X SMAN 2 Brastagi kabupaten tanah karo tahun pembelajaran 2016-2017.

c. Untuk mengetahui peningkatan strategi pembelajaran SFAE terhadap motivasi belajar tingkat rendah dalam keterampilan menulis karangan deskripsi oleh siswa kelas X SMAN 2 Brastagi kabupaten tanah karo tahun pembelajaran 2016-2017.

\section{Metode}

Metode penelitian ini adalah eksperimen. Dengan Disain penelitian ini adalah faktorial $2 \mathrm{x}$ 3.Dalam penelitian ini terdapat tiga variabel penelitian yaitu satu variabel terikat dan dua variabel bebas. Sebagai variabel terikat adalah keterampilan menulis karangan deskripsi dan dua variabel lainnya adalah variabel bebas yaitu strategi pembelajaran(A) dan motivasi belajar (MB).Variabel bebas yang dimaksud adalah variabel perlakuan dan variabel moderator. Variabel perlakuan dibedakan menjadi dua yaitu strategi 
pembelajaran Student Facilitator And Explaining (A1) untuk kelompok eksperimen dan strategi pembelajaran Examples Non Examples (A2) untuk kelompok kontrol.Sedangkan variabel moderator yaitu motivasi belajar peserta didik $(\mathrm{Mb})$ dibedakan menjadi tiga tipe yaitu motivasi belajar tinggi (Mb1), motivasi belajar sedang (Mb2), dan motivasi belajar rendah (Mb3). Adapundisain faktorial $2 \times 3$ adalah sebagai berikut:

\section{Hasil Dan Pembahasan}

Hasil penelitian ini adalah data Kombinasi Strategi Pembelajaran Dengan Motivasi Belajar Dalam Meningkatkan Keterampilan Menulis Karangan Deskripsi Siswa Kelas X SMAN 2 Berastagi Kabupaten Tanah Karo Tahun 2016/2017. Data yang disajikan dapat dilihat pada tabel di bawah ini:

Tabel 2. Data hasil penelitian anava dua jalur

\begin{tabular}{|l|l|l|l|}
\hline \multirow{2}{*}{$\begin{array}{l}\text { Motivasi } \\
\text { Belajar (B) }\end{array}$} & & \multicolumn{2}{|c|}{ Strategi Pembelajaran $(\mathrm{A})$} \\
\cline { 2 - 4 } MB (B) & & $\mathrm{SFAE}\left(\mathrm{A}_{1}\right)$ & $\mathrm{ENE}\left(\mathrm{A}_{2}\right)$ \\
\cline { 2 - 4 } & $\mathrm{TB}_{1}$ & $\mathrm{~A}_{1} \mathrm{~B}_{1}$ & $\mathrm{~A}_{2} \mathrm{~B}_{1}$ \\
\cline { 2 - 4 } & $\mathrm{SB}_{2}$ & $\mathrm{~A}_{1} \mathrm{~B}_{2}$ & $\mathrm{~A}_{2} \mathrm{~B}_{2}$ \\
\cline { 2 - 4 } & $\mathrm{RB}_{3}$ & $\mathrm{~A}_{1} \mathrm{~B}_{3}$ & $\mathrm{~A}_{2} \mathrm{~B}_{3}$ \\
\hline
\end{tabular}

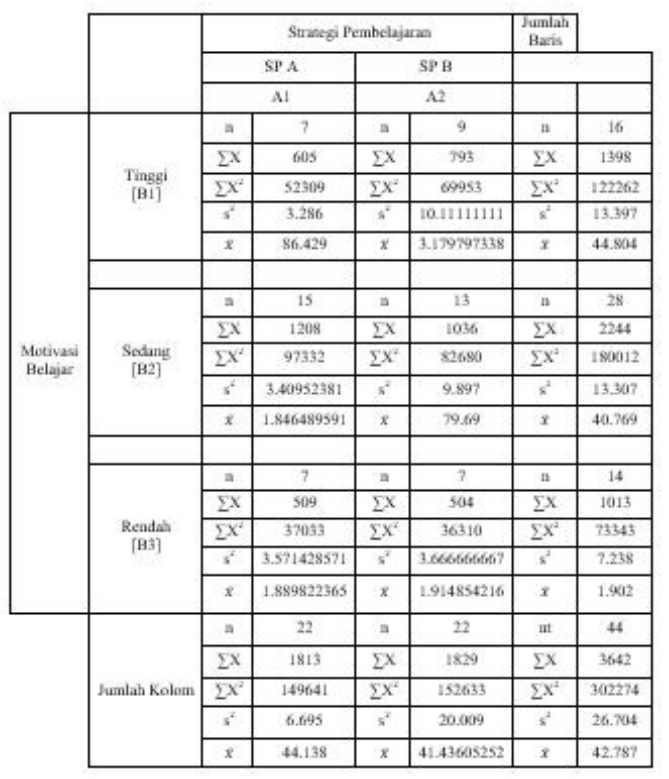

Berdasarkan hasil pengujian persyaratan analisis data menunjukkan bahwa data telah memenuhi persyaratan analisis data yakni data berdistribusi normal dan berasal dari populasi homogen. Oleh karena itu, selanjutnya dilakukan analisis data dengan menggunakan analisis varians dua jalur. Adapun hasil hitung analisis varians dua jalur dapat dilihat pada tabel di bawah ini:

\begin{tabular}{|c|c|c|c|c|c|}
\hline \multirow{2}{*}{$\begin{array}{l}\text { Sumber } \\
\text { Varrasis }\end{array}$} & \multirow{2}{*}{$\mathrm{db}$} & \multirow{2}{*}{ JK } & \multirow{2}{*}{$\mathrm{kK}=\mathrm{JK} / \mathrm{db}$} & F hitumg & \multirow{2}{*}{$\mathrm{F}_{\text {tabsel }}$} \\
\hline & & & & $F_{2}=$ RK $R K D$ & \\
\hline $\begin{array}{l}\text { Molivasi } \\
\text { Belajar }\end{array}$ & 1 & 537.55 & 537.55 & 79751 & 379 \\
\hline $\begin{array}{l}\text { Strategi } \\
\text { Pembelajaran }\end{array}$ & 1 & 5.82 & 5.82 & 0.871 & 3.79 \\
\hline Interaksi & 1 & 1075 & 1075 & 1536 & 379 \\
\hline Dalami & 40 & 267.11 & 6.68 & --- & $\cdots$ \\
\hline $\begin{array}{l}\text { Total } \\
\text { Dirediksi }\end{array}$ & 43 & 815.73 & - & -- & -- \\
\hline
\end{tabular}




\section{Kesimpulan}

a. Ada perbedaan keterampilan menulis karangan siswa yang memiliki motivasi belajar. Keterampilan menulis karangan siswa yang memiliki motivasi belajar tinggi, sedang dan rendah adalah berbeda;

b. Tidak ada perbedaan keterampilan menulis karangan siswa yang belajar dengan strategi pembelajaran student facilitator and explaining dan examples non example;

c. Tidak ada interaksi antara strategi pembelajaran dan motivasi belajar siswa dalam meningkatkan keterampilan menulis karangan.

Berdasarkan kesimpulan di atas maka analisis lanjut menggunakan uji Scheffe untuk mengetahui perbedaan keterampilan menulis karangan siswa tidak dapat dilakukan hal ini disebabkan karena tidak ada interaksi strategi pembelajaran dan motivasi belajar siswa dalam meningkatkan keterampilan menulis karangan.

\section{Daftar Pustaka}

Ananta, Wirandya. 2014.

Pengaruh Model

Pembelajaran SFAE

TerhadapKemampuan

Pemecahan Masalah

Matematika. Jurnal PGSD,

Vol 2, No1, 2014:1-10.

Anonim. 2010. Macammacam

motivasi:blogspot.com

(diakses pada tanggal 08

Agustus 2016)

Depdikbud. 2003.

Keterampilan Menulis

Dalam Kamus Besar

BahasaIndonesia. Jakarta

Finoza, 2008. Jenis-jenis

Karangan

al 08 Agustus 2016.

Hari, Kurniadi. 2010. Modelmodel

Pembelajaran.blogspot.com , diakses pada tanggal 08 Agustus 2016.

Kuswari. 2008. Menulis Sebagai

KeterampilanProduktif.blo gspot.com, diakses pada tanggal 08 Agustus2016.

Mappuase, M, Yusuf. 2009. Jurnal Medtek, Vol 1 No 2 tahun 2009.

Nurgiyantoro.2011.

Keterampilan Menulis. Yogyakarta: Pessindo.

Rocyandi. 2003. Model Pembelajaran

ENE:blogspot.com, diakses pada tanggal 10 Agustus 2016.

Sumarianto. 2010. Menulis. Bandung: Pakar Karya

Sri, Astuti, Endang. 2010. Motivasi Belajar. Jakarta: Pena Gading.

Sanjaya. 2011. Model Student Facilitator And Explaining. 
Jakarta: Grasido. Prasetyo.

$2011 . \quad$ Model

Pembelajaran SFAE

dan ENE.

Blogspot.com, diakses pada tanggal 08 Agustus 2016. Yunita dalam Purniwati. 2011. Meningkatkan Kemampuan Kognitif Siswa

Melalui Model Pembelajaran SFAE Pada Pelajaran IPAKelas V SD

Negeri Sei Rotan. Jurnal PGSD, Vol 1, No 1 tahun 2012:1-10 
Jurnal Penelitian Pendidikan Bahasa dan Sastra Vol. 2 No. 2. Oktober 2017 